\title{
Detection of antibiotic resistance genes among multiple drug resistant Pseudomonas aeruginosa strains isolated from clinical sources in selected health institutions in Kwara State.
}

\author{
*Adekunle O.C. ${ }^{1}$, Mustapha A. ${ }^{2}$, Odewale G. ${ }^{3}$, Ojedele R.O. ${ }^{4}$
}

\begin{abstract}
Introduction Pseudomonas aeruginosa (P. aeruginosa) is a frequent nosocomial pathogen that causes severe diseases in many clinical and community settings. The objectives were to investigate the occurrence of multiple antibiotic resistant $\mathrm{P}$. aeruginosa strains among clinical samples and to detect the presence of antibiotic resistance genes in the DNA molecules of the strains.
\end{abstract}

Methods: Clinical specimens were collected aseptically from various human anatomical sites in five selected health institutions within Kwara State, Nigeria. Multiple drug resistance patterns of isolated micro-organisms to different antibiotics were determined using the Bauer Kirby disc diffusion technique. The DNA samples of the multiple resistant $P$. aeruginosa strains were extracted and subjected to Polymerase Chain Reaction (PCR) for resistance gene determination.

Results: A total of 145 isolates were identified as P. aeruginosa from the clinical samples. Absolute resistance to ceftazidime, gentamicin and ceftriaxone was observed while low resistance to ciprofloxacin, piperacillin and imipenem was documented. The prevalence of $b l a_{\mathrm{VIM}}, b l a_{\text {СТХ-м }}$ and $b l a_{\text {тЕм }}$ were $34.4 \%$, $46.7 \%$ and $16.7 \%$ respectively.

Conclusion: This study has shown that there is a high occurrence of metallo $\beta$-lactamase- producing and antibiotic-resistant strains of $P$. aeruginos $a$ in clinical specimens from the studied area.

Keywords: Metallo $\beta$-lactamase enzyme, P. aeruginosa, clinical samples, antibiotic-resistance genes.

\author{
*Corresponding Author \\ Adekunle O.C \\ Email: toyintoro@yahoo.com; olutoyin.adekunle@uniosun.edu.ng
}

\footnotetext{
${ }^{1}$ Department of Medical Microbiology and Parasitology, Osun State University, Osogbo, Nigeria

${ }^{2}$ Department of Microbiology, Kwara State University, Ilorin, Nigeria

${ }^{34}$ Department of Medical Microbiology and Parasitology, Ladoke Akintola University of Technology, Ogbomoso, Nigeria.
} 


\title{
Détection de gènes de résistance aux antibiotiques parmi plusieurs souches de Pseudomonas aeruginosa résistantes aux médicaments isolés à partir de sources cliniques dans des établissements de santé sélectionnés dans l'état de Kwara
}

\author{
*Adekunle O.C. ${ }^{1}$, Mustapha A. ${ }^{2}$, Odewale G. ${ }^{3}$, Ojedele R.O. ${ }^{4}$
}

Objectifs de l'étude: Pseudomonas aeruginosa (P. aeruginosa) est un pathogène nosocomial fréquent qui provoque des maladies graves dans de nombreux contextes cliniques et communautaires. Les objectifs étaient d'étudier la présence de multiples souches de $P$. aeruginosa résistantes aux antibiotiques parmi des échantillons cliniques et de détecter la présence de gènes de résistance aux antibiotiques dans les molécules d'ADN des souches.

Méthode de l'étude : Des échantillons cliniques ont été prélevés de manière aseptique sur divers sites anatomiques humains dans cinq établissements de santé sélectionnés dans l'état de Kwara, au Nigéria. De multiples profils de résistance aux médicaments de micro-organismes isolés à différents antibiotiques ont été déterminés à l'aide de la technique de diffusion sur disque de Bauer Kirby. Les échantillons d'ADN des multiples souches résistantes de $\mathrm{P}$. aeruginosa ont été extraits et soumis à une réaction en chaîne par polymérase (PCR) pour la détermination des gènes de résistance.

Résultat de l'étude : Un total de 145 isolats a été identifié comme P. aeruginosa à partir des échantillons cliniques. Une résistance absolue à la ceftazidime, à la gentamicine et à la ceftriaxone a été observée tandis qu'une faible résistance à la ciprofloxacine, à la pipéracilline et à l'imipénem a été documentée.

Conclusion : Cette étude a montré qu'il existe une forte occurrence de souches productrices de métallo $\beta$ lactamases et résistantes aux antibiotiques de P. aeruginosa dans les échantillons cliniques de la zone étudiée.

Mots-clés : Enzyme métallo $\beta$-lactamase, $P$. aeruginosa, échantillons cliniques, gènes de résistance aux antibiotiques.

\author{
*Corresponding Author \\ Adekunle O.C \\ Email: toyintoro@yahoo.com; olutoyin.adekunle@uniosun.edu.ng
}

\footnotetext{
${ }^{1}$ Department of Medical Microbiology and Parasitology, Osun State University, Osogbo, Nigeria

${ }^{2}$ Department of Microbiology, Kwara State University, Ilorin, Nigeria

${ }^{34}$ Department of Medical Microbiology and Parasitology, Ladoke Akintola University of Technology, Ogbomoso, Nigeria.
} 


\section{INTRODUCTION}

Pseudomonas aeruginosa is a bacterium characterized by its high genetic plasticity and potential for adapting to various environments. The species are frequently isolated from soil and water or colonize several anatomical sites of plants, insects, animals, and humans $(1,2)$. The bacterium may be involved in food infection and has many virulence factors $(3,4)$.

$P$. aeruginosa is widespread in natural environments and considered as an opportunistic secondary pathogen for humans that is capable of causing major nosocomial infections and a broad spectrum of infections including urinary tract infection, burns, respiratory tract infection, meningitis, chronic otitis media and otitis externa, pseudomonal endocarditis and septicemia $(5,6)$. The extensive use of antimicrobial agents and the evolution of antimicrobial resistance strategies by bacteria have resulted in the emergence of nosocomial bacterial pathogens (superbugs) with acquired resistance to almost all available antimicrobial agents (7). These superbugs have severely threatened therapeutic choices in the last few decades $(8,9)$. $P$. aeruginosa is considered multidrug resistant (MDR) if the isolate is resistant to more than two of the following drugs: piperacillin/tazobactam, ceftazidime, aztreonam, amikacin, gentamicin, ciprofloxacin, imipenem, meropenem and colistin $(10,11)$. These agents are representatives of the primary antibiotic classes used in the treatment of $P$. aeruginosa infections.

$P$. aeruginosa uses distinctive mechanisms to become resistant to a wide range of antimicrobials agents $(12,13)$. These include the up-regulation of efflux systems, decreased outer membrane permeability and $\beta$ - lactamase production. However, acquired extended spectrum $\beta$-lactamase (ESBL) and metallo $\beta$ lactamase (MBL) mediated resistance is important in emerging resistance mechanisms of $P$. aeruginosa $(14,15)$. P. aeruginosa has been reported to have constitutive expression of multidrug efflux pumps and AmpC $\beta$-lactamase associated with loss in permeability of the outer membrane (16). Therefore, this study is aimed at investigating the occurrence of metallo $\beta$ Lactamase enzyme and detecting antibiotic resistance genes among multiple antibiotic resistant $P$. aeruginosa isolated from clinical samples.

\section{MATERIALS AND METHODS \\ Description of Study Location}

The selected hospitals and healthcare located in Kwara State, Nigeria facilities provide quality health care services to the residents of the State and neighbouring States like Oyo, Kogi, Niger, Osun, and Ekiti. Ilorin is the capital of Kwara State in the central Nigeria, West Africa. Ilorin coordinates on the globe at $8^{\circ} 30^{\prime} \mathrm{N} 4^{\circ} 33^{\prime} \mathrm{E}$.

\section{Sample Collection}

One hundred and forty five strains of $P$. aeruginosa were isolated from two hundred and thirty five clinical samples which included urine, wound, sputum, blood and indwelling medical devices. Well labelled screw-top containers were used to collect mid-stream urine. Swab samples were taken by expert technicians from hospitalized patients admitted to burn ward. The swabs were collected in sterile normal saline $(0.85(\mathrm{w} / \mathrm{v}))$ with all aseptic precautions. Sputum was produced by coughing from deep in the chest and coughed into plastic collection bottle.

Ethical considerations: Ethical approval was obtained from the Ethical Review Committee (ERC) of Kwara State Ministry of Health, Ilorin.

\section{Isolation of $P$. aeruginosa and Bacterial examination}

The clinical samples were collected into a transport medium (Nutrient broth) before transporting to the laboratory. The collected samples were inoculated into nutrient broth for culture $42^{\circ} \mathrm{C}$ for 24 hours. The overnight broth culture was further sub-cultured on MacConkey agar and Blood Agar. Incubation of the cultured plates was done under aerobic conditions. The bacterial growth was observed for colonies morphologically resembling $P$. aeruginosa. $P$. aeruginosa formed smooth round colonies with a fluorescent greenish colour. Colonies morphologically resembling $P$. aeruginosa were subjected to further characterization.

\section{Confirmation of Pseudomonas aeruginosa strains}

The test for the identification of $P$. aeruginosa in clinical samples was carried out using cetrimide agar for confirmation. Morphological Characterization such as Gram Staining and Biochemical Characterization such as indole, citrate, and oxidase tests were carried out. Results obtained were compared with specifications in $21^{\text {st }}$ edition of Bergey's Manual of Systematic Bacteriology. 


\section{Antimicrobial susceptibility testing}

Antibiotic susceptibility testing was performed using modified Kirby-Bauer disk diffusion method following the guidelines of Clinical and Laboratory Standards Institute (CLSI, 2015).

\section{Metallo $-\beta$ lactamase detection}

The inoculum of Pseudomonas aeruginosa was prepared (CLSI, 2015). Each isolate of $P$. aeruginosa was inoculated on a separate Mueller Hinton plate. MBL E-test strips containing concentration gradients $(1-64 \mu \mathrm{g} / \mathrm{ml})$ of imipenem (IP) on one end of the strip and imipenem overlaid with a constant concentration of EDTA (IPI) on the other end of the strip were placed onto the plate and incubated at $42^{\circ} \mathrm{C}$ aerobically for 18-24 hours as shown in plates 1 and 2. Negative control was set along with the test using $P$. aeruginosa ATCC 27853. A reduction in the imipenem minimum inhibitory concentration (MIC) in the presence of EDTA of greater than or equal to eight-fold (IP/IPI $\geq 8$ ) indicated MBL positivity.

\section{Detection of multiple drug resistant Pseudomonas aeruginosa}

Multiple drug resistance in $P$. aeruginosa isolates was defined as resistance to three or more Pseudomonal anti-microbial classes (18).

\section{DNA Extraction and Amplification in Thermal Cycler}

Five (5) colonies of the isolate was scooped into a sterile microtube containing 200 $\mu 1$ of 1 X TBE. It was boiled for 15 minutes after which the preparation was allowed to cool rapidly on ice at $-20{ }^{\circ} \mathrm{C}$ for 30 minutes. It was incubated for 20 minutes at $66{ }^{\circ} \mathrm{C}$. The lysate was centrifuged ( $5 \mathrm{~min}$ at $13,000 \mathrm{rpm}$ ), and $3 \mu \mathrm{l}$ of the supernatant was used as the DNA sample for the PCR reaction.

For PCR amplification, a total volume of $20 \mu 1$ reaction mix containing $2 \mu 1$ of $10 \mathrm{X}$ buffer, $1 \mu \mathrm{I} \mathrm{MgCl}_{2}, 0.8 \mu \mathrm{l}$ dNTPs, $0.5 \mu 1$ of forward primer, $0.5 \mu 1$ of reverse primer, $0.2 \mu 1$ Taq polymerase, $10 \mu \mathrm{l}$ of nuclease free water and $5 \mu$ of DNA lysate was used.

The polymerase chain reaction was set up in a PCR vial after adding the master mix, the forward and reverse primers and the extracted DNA. Amplification was subjected to initial denaturation at $95^{\circ} \mathrm{C}$ for 5 minutes, followed by 35 cycles of denaturation at $95^{\circ} \mathrm{C}$ for 1 minute, annealing at $60^{\circ} \mathrm{C}, 54^{\circ} \mathrm{C}, 47^{\circ} \mathrm{C} 50^{\circ} \mathrm{C}$ for 1 minute, for CTX-M, VIM, IMP and oprD respectively, extension at $72{ }^{\circ} \mathrm{C}$ for 1 minute and final extension procedure was carried out at $72 \mathrm{C}^{\circ}$ for 10 minutes. Primers used are shown in Table 1.

\section{Agarose gel electrophoresis}

The PCR products were analyzed after electrophoresis in $1.5 \%$ agarose gel stained with ethidium bromide to detect specific amplified products by comparing with standard molecular weight marker.

\section{Data analysis}

Data were entered into the computer and statistical analysis was performed using Chisquare. P values $\leq 0.05$ were assumed statistically significant.

\section{RESULTS}

Out of the $145 P$. aeruginosa isolates examined, 30 (21\%) were MBL-producing while $115(79 \%)$ were negative for MBL production.

During the study period, MBL positive isolates were found to be resistant to ceftriaxone and ceftazidime $(100 \%)$ while the susceptibility patterns of the MBL negative isolates to these antibiotics were $55(37.9 \%)$ and $90(62.1 \%)$ respectively as presented in Table 2 .

Plate 1 displays the photograph of MBL positive $P$. aeruginosa showing a phantom zone which is characteristic of MBL producers while plate $\mathbf{2}$ displays the photograph of MBL positive $P$. aeruginos a showing IP/IPI $\geq 8$

Electrophoresis gel picture of the amplified resistance genes showed oprD gene at band $585 \mathrm{bp}, c t x-M$ gene at band $1300 \mathrm{bp}$, VIM gene at band 390 bpand TEM gene at band 517 bp (Figures $1-4)$.

\section{DISCUSSION}

Pseudomonas aeruginosa is commonly implicated as a cause of health care acquired infections with high mortality rates (19). High rate of microbial resistance to the cephalosporins among the $P$. aeruginosa isolates was observed in this study. The high incidence of resistance to the cephalosporins and quinolones may be attributed to cross-resistance which may be as a result of indiscriminate use of ciprofloxacin in the studied area. Resistance of the isolates to betalactam antibiotics showed an increased betalactamase enzyme production among the isolates. All the MBL producing isolates were resistant to ceftriaxone $(100 \%)$, ceftazidime and ciprofloxacin $(100 \%)$ respectively as was also observed by Oladipo et al. (20) who reported high 
prevalence of cephalosporin resistant $P$. aeruginosa isolates among in- and out-patients.

In this study the prevalence of MBL producing P.aeruginosa was found to be $21 \%$. This result was lower than the $36.07 \%$ reported by Sasirekha et al., (21) and higher than the prevalence reported in Lagos (22), and in Belgium (23): $4.1 \%$ and $4.4 \%$ respectively. It is also higher than the prevalence of $10.0 \%$ and $14.0 \%$ obtained in Enugu, South east Nigeria (24) and India (25) respectively.

The highest rates of susceptibility of $P$. aeruginosa isolates were recorded for colistin $(77.2 \%)$ followed by imipenem $(65.5 \%)$. This result for colistin corroborates studies from Nwankwo and Shaibu and Aibinu et al. (22) who reported $78.9 \%$ and $95.6 \%$ susceptibility rates respectively for $P$. aeruginosa isolates. Colistin is nephrotoxic, which is why it is always used as a last resort drug for resistant strains. It is therefore not abused; this explains the high susceptibility of the isolates to the drug.

Gentamicin on the other hand had less activity and showed same microbial resistance profile as the $\beta$-lactam drugs. The reason for this high resistance to gentamicin could be as a result of indiscriminate use of the drug in this area. The drug, though a prescription only medicine is purchased as over-the-counter in the open markets littered in the community and is commonly used by unqualified personnel in the treatment of "infections". Several studies have shown that gentamicin is effective against Pseudomonas species but if misused, the organisms may develop resistance to them. These research findings are similar to that of Sasirekhaet al. (21) where they recorded 82.1 $\%$ susceptibility of the isolates to gentamicin.In previous studies by Oduyebo et al. (26) in Kwara state, $P$. aeruginosa strains were found to be highly susceptible to the ciprofloxacin and well tolerated. This result implies that quinolones alone, cannot be depended upon as an antipseudomonal antimicrobial in this area. They will have to be used in combination or replaced with another antimicrobial preferably the broadspectrum beta-lactams/penicillins. In the present study, isolates positive for oprD gene were 42 (46.7\%), VIM gene 31 (34.4\%), ctx- $M$ gene 15 $(16.7 \%)$, TEM gene $34(37.7 \%)$ respectively. The prevalence of oprD gene in this study is lower than $90 \%$ reported by Eucharia et al. (27). The prevalence of VIM gene observed from this study is lower than $52.3 \%$ reported by Shaikh et al. (28) and higher than $2.5 \%$ obtained from Zubair and Iregbu, (29). Also, from this study the result of $c t x-M$ gene is slightly lower than $55.7 \%$ reported by Shaikh et al. (28) while the TEM gene is higher in this study as compared $31.4 \%$ reported by Shaikh et al. (28). The resistance to these drugs is a major problem for chemotherapy and pro-active measures must be put in place at various levels to forestall this trend.

\section{CONCLUSION}

Effective and good antibiotic prescription as well as infection control practices must be put in place to prevent therapeutic failures and further spread of the resistance genes.

Ethic approval and consent to participate: Ethical approval was obtained from the ethical review committee (erc) of kwara state ministry of health, ilorin.

Authors' contributions: AOC, MA, OG and ORO were involved in the conception and design, data collection and collation, data analysis, data interpretation and manuscript proofreading.

Conflict of interest: The authors declare no conflict of interest, financial or otherwise.

\section{REFERENCES}

1. Edelstein MV,Skleenova EN, Shevchenko OV, D'souza JW, Tapalski DV, et. al. Spread of extensively resistant VIM-2-positive ST235 Pseudomonas aeruginosa in Belarus, Kazakhstan, and Russia: a longitudinal epidemiological and clinical study. Lancet Infect. Dis.2013;13(10): 867-876.

2. Tiwari N, Rajdev S, Mullan S. Resistance Trends among 1t;igt;Pseudomonasaeruginosalt;/igt; Isolates in a Tertiary Care Centre in South Gujarat. Adv. Microbiol.2017;7(3): 188-194. http://dx.doi.org/10.4236/aim.2017.73015

3. Lavoie EG, Wangdi T, Kazmierczak BI. Innate immune responses to Pseudomonas aeruginosa infection. Microbes Infect.2011;13(14-15): 1133-1145.

4. Strateva T, Yordanov D.Pseudomonas aeruginosa - a phenomenon of bacterial resistance. J. Med. Microbiol.2009; 58(Pt 9):1133-1148.

5. Poorabbas B, Mardaneh J, Rezaei Z., Kalani M, Pouladfar G, Alami MH, et. Al. Nosocomial Infections: Multicenter surveillance of antimicrobial resistance profile of Staphylococcus aureus and Gram negative rods isolated from blood and other sterile body fluids in Iran. Iran. J. Microbiol.2015;7(3): 127-135.

6. Meletis G, Exindari M, Vavatsi N, Sofianou D, Diza E. Mechanisms responsible for the emergence of carbapenem resistance in Pseudomonas aeruginosa.Hippokratia, 2012;16(4):303-307. 
7. Zavascki AP, Barth AL, Goncalves ALS, Moro LD, Fernandes JF, Martin AF, et al. The influence of metallo-b-lactamase production on mortality in nosocomial Pseudomonas aeruginosa infections. J. Antimicrob. Chemother. 2006;58(2):387-392

8. Anvarinejad M, Japoni A, Rafaatpour N, Mardaneh J,.Abbasi P, Amin Shahidi M, et.al. Burn Patients Infected With Metallo-BetaLactamase-Producing Pseudomonas aeruginosa: Multidrug-Resistant Strains. Arch. Trauma Res.2014,3(2):181-82.

9. Bali EB, Aç L, Sultan N. Phenotypic and molecular characterization of SHV, TEM, CTX$\mathrm{M}$ and extended-spectrum-lactamase produced by Escherichia coli, Acinobacterbaumannii and Klebsiella isolates in a Turkish hospital. African Journal.2010.

10. Falagas ME, Kastoris AC, Karageorgopoulos DE, Rafailidis PI. Fosfomycin for the treatment of infections caused by multidrug-resistant nonfermenting Gram-negative bacilli: a systematic review of microbiological, animal and clinical studies. Int. J. Antimicrob. Agents. 2009;34(2): 111-120.

11. Fang H, Ataker F, Hedin G, Dornbusch K. Molecular epidemiology of extended spectrum $\beta$ Lactamases among Escherichiacoli isolates collected in a Swedish hospital and its associated health care facilities from 2001 to 2006 . Journal of Clinics Microbiological.2008;46(2):707-712.

12. Giske CG, Monnet DL, Cars O, CarmeliY. ReAct-Action on Antibiotic Resistance. Clinical and economic impact of common multidrugresistant gram-negative bacilli. Antimicrob. Agents Chemother.2008;52(3): 813-821.

13. Grover SS, Sharma M, Chattopadhya D, Kapoor $\mathrm{H}$, Pasha ST, Singh G. Phenotypic and genotypic detection of ESBL mediated cephalosporin resistance in Klebsiellapneumoniae: emergence of high resistance against cefepime, the fourth generation cephalosporin. J. Infect.,2006; 53(4): 279-288.

14. El Salabi A,Borra PS, Toleman MA, Samuelsen O, Walsh TR. Genetic and biochemical characterization of a novel metallo- $\beta$-lactamase, TMB-1, from an Achromobacterxylosoxidans strain isolated in Tripoli, Libya. Antimicrob. Agents Chemother.2012;56(5): 2241-2245.

15. Janvier F, Jeannot K, Tessé S, Robert-Nicoud M, Delacour H, Rapp C, Mérens A. Molecular characterization of blaNDM-1 in a sequence type 235 Pseudomonas aeruginosa isolate from France. A n t i mi crob. A gents Chemother.2013;57(7):3408-3411.

16. Gupta A, Ampofo K, Rubenstein D,Saiman, L. Extended spectrum beta lactamase-producing Klebsiellapneumoniae infections: a review of the literature. J. Perinatol.2003;23(6): 439-443.

17. Paphitou NI. Antimicrobial resistance: Action to combat the rising microbial challenges. Int. J.
Antimicrob. Agents. 2013; 42 Suppl:S25-8

18. CLSI. Performance Standards for Antimicrobial Susceptibility TestingCLSI supplement M100S, 26th ed.; Wayne: PA: Clinical and Laboratory Standards Institute.,2016.

19. Alabi OS,Obisesan AO, Ola AA. Prevalence of Methicillin-resistant Staphylococcus aureus and Extended spectrum B-lactamase producers among Bacteria Isolated from Infected Wounds in a Tertiary Hospital in Ibadan City. Afr. J. Clin. Exp. Microbiol.2016;17(4):235-242.

20. Oladipo EK, Oloke JK, Omomowo IO, Oyeniran AO, Awoyelu EH, Ogundele S.O. Incidence of cephalosporin resistance among clinical isolates of Pseudomonas aeruginosa in Ibadan, SouthWestern Nigeria. Int. J. Med. Biomed. Res.2015;4:135-141.

21. Sasirekha B, Manasa R, Ramya P, Sneha R. Frequency and Antimicrobial Sensitivity Pattern of Extended Spectrum Beta- Lactamases Producing E.coli and Klebsiella pneumonia Isolated in a Tertiary Hospital. Al Ameen J. Med. Sci.2010;3(4): 265-271.

22. Aibinu I, Nwanneka T, Odugbemi T. Occurence of ESBL and MBL in clinical isolates of Pseudomonas aeruginosa from Lagos, Nigeria. J.Am.Sci.2007;3(4): 81-85.

23. Bergès L, Rodriguez-Villalobos H, Deplano A, Struelens MJ. Prospective evaluation of imipenem/EDTA combined disc and Etest for detection of metallo- $\beta$-lactamase-producing Pseudomonas aeruginosa. J. Antimicrob. Chemother.2007;(4): 812-813.

24. Ejikeugwu C, Ugwu M, Iroha M, Eze P, Gugu T, Esimone C. Phenotypic detection of Metallo - $\beta-$ lactamase (MBL) enzyme in Enugu, Southeast Nigeria. America Journal of Biological. Chemical and Pharmaceutical Sciences.2014;2(2): 1-6.

25. Hemalatha V, Sekar U, Kamat V. Detection of metallobetalactamase producing Pseudomonas aeruginosa in hospitalized patients. Indian $J$. Med. Res.2005;122(2): 148-152.

26. Oduyebo O, Ogunsola FT, Odugbemi T. Prevalence of Multi - Resistant Strains of Pseudomonas aeruginosa Isolated at the Lagos University Teaching Hospital Laboratory. Nigeria Journal of Hospital Medicine. 1997; 7(4): 1-4.

27. Eucharia E, NmemaChioma S, Osuagwu Eunice N. Anaele:oprD Genes Detected in Pseudomonas aeruginosa Isolates from a Teaching Hospital but Lost in a Carbapenem-Resistant Strain. Journal of Advances in Medicine and Medical Res. 2019;29(9): 1-8.

28. Shaikh S, Fatima J, ShakilS, DanishRizvi, SM, Kamal M.A. Prevalence of multidrug resistant and extended spectrum beta-lactamase producing Pseudomonas aeruginosa in a tertiary care hospital. Saudi J. Biol. Sci.2015;22(1):62-64.

29. Zubair KO, Iregbu KC. Resistance pattern and 
detection of Metallo-beta-lactamase genes in Clinical Isolates of Pseudomonas aeruginosa in a Central Nigeria tertiary hospital. Nigerian Journal of Clinical Practice. 2018;21(2):176-182 
Table 1: Primers used for the Amplification of genes

\begin{tabular}{|c|c|c|c|c|}
\hline Primer & Sequence $5^{1}-3^{1}$ & $\begin{array}{l}\text { Base } \\
\text { pair (bp) }\end{array}$ & $\begin{array}{l}\text { Annealing } \\
\text { Temp. }\left({ }^{\circ} \mathrm{C}\right)\end{array}$ & Reference \\
\hline$C T X-M F$ & CGATGTGCAGTACCAGTAA & 585 & 60 & Lim et al. \\
\hline$C T X-M F$ & CGATGTGCAGTACCAGTAA & 585 & 60 & $(2009)$ \\
\hline$C T X-M R$ & CGATGTGCAGTACCAGTAA & & & \\
\hline VIM2004A & GTTTGGTCGCATATCGCAAC & 390 & 54 & $\begin{array}{l}\text { Fazeli et al. } \\
(2009)\end{array}$ \\
\hline VIM2004A & AATGCGCAGCACCAGGATAG & & & \\
\hline BLATEM F & TGAGCAAGTTATCTGTATTC & 931 & 47 & $\begin{array}{l}\text { Lim et al., } \\
(2009)\end{array}$ \\
\hline BLATEMR & TTAGTTGCTTGGTTTTGATG & & & \\
\hline$O P R D F$ & ATGAAAGTGATGAAGTGGAG & 1329 & 50 & $\begin{array}{l}\text { Fazeli et al. } \\
\text { (2013) }\end{array}$ \\
\hline$O P R D R$ & CAGGATCGACAGCGGATAGT & & & \\
\hline
\end{tabular}

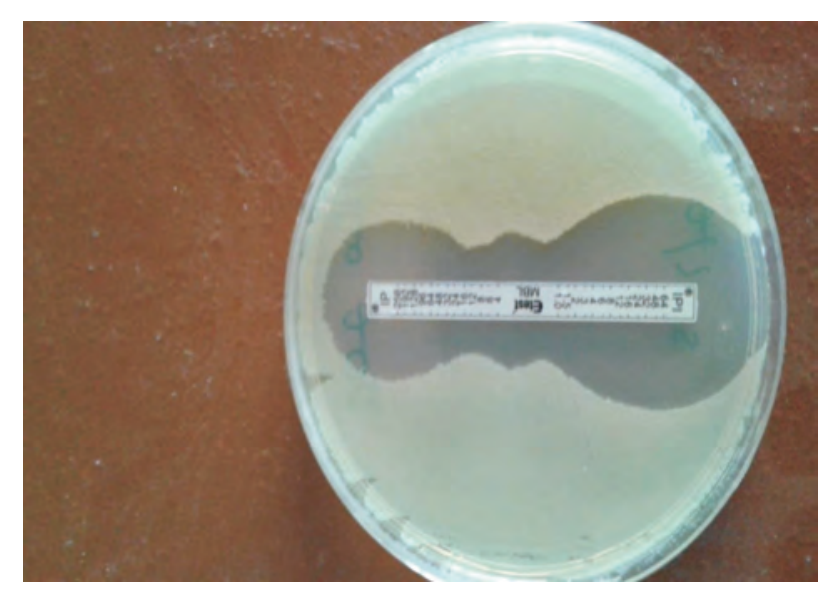

Plate 1: Photograph of MBL positive $P$. aeruginosa showing a phantom zone which is characteristic MBL producers.

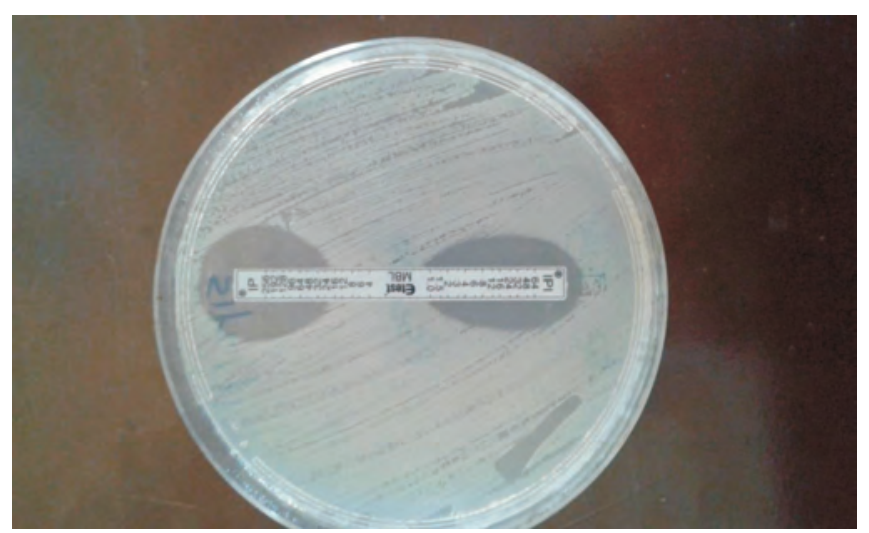

Plate 2: Photograph of MBL positive $P$. aeruginosa showing IP/IPI=8. 


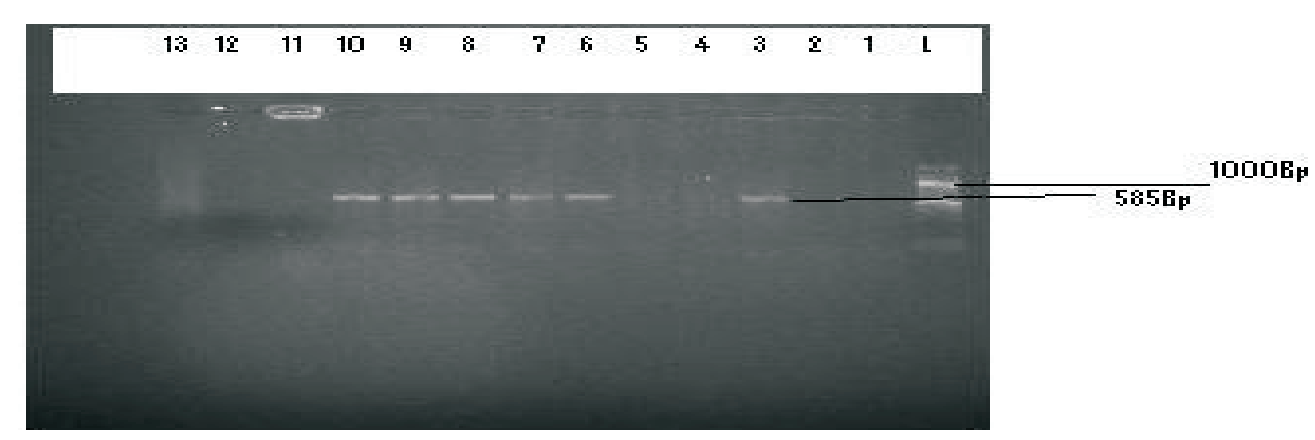

Figure 1: Agarose gel electrophoretogram of oprD gene.

Lane1: Negative control; Lanes 6, 7, 8, 9 and 10: oprD gene positive isolates; lane 3: positive control, L: Ladder, $100 \mathrm{bp}$

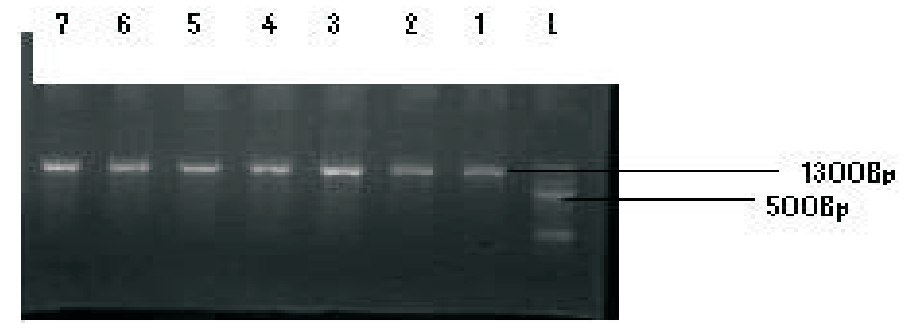

Figure 2: Agarose gel electrophoretogram of $c t x$ - $M$-type $\beta$-lactamaseafter PCR which bands at $1300 \mathrm{bp}$.

Lane 1: Positive control; Lanes 2-7 positive for $c t x-M$ gene. L is the ladder (100bp).

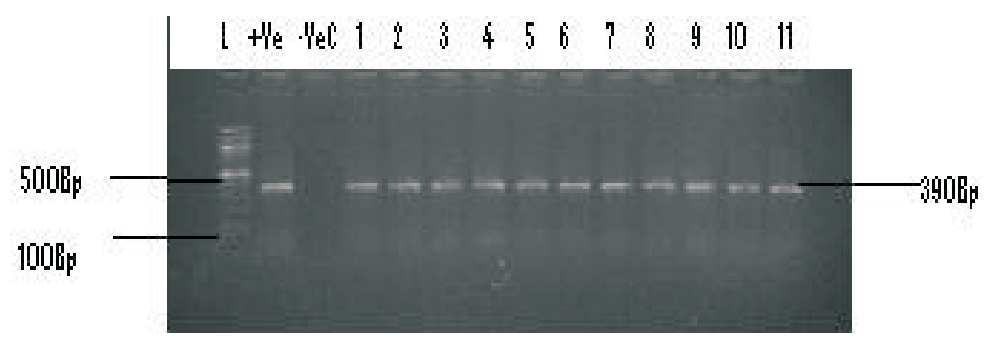

Figure 3: Agarose gel electrophoretogram of (VIM) after PCR which bands at $390 \mathrm{bp}$ L: DNA Ladder; Lane2: Positive control; Lane 3: Negative control; Lane 1-11: Presence of VIM gene.

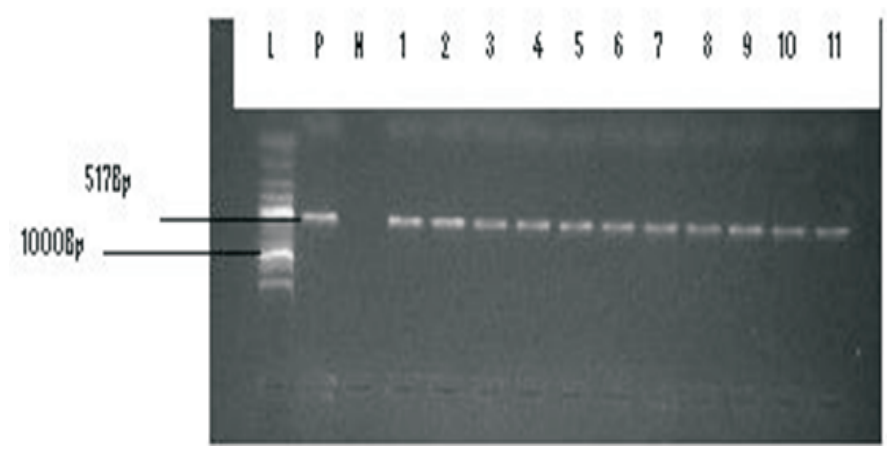

Figure 4: Agarose gel electrophoretogram of TEM after PCR which bands at $517 \mathrm{bp}$ L: Ladder; Lane P: Positive control lane N: Negative control; Lanes 1-11: TEM gene positive isolates. 